\title{
Nitrogen and Phosphorus Dynamics in the Waters of the Great Ruaha River, Tanzania
}

\author{
Matobola Joel Mihale \\ Department of Physical Sciences, Open University of Tanzania, Dar es Salaam, Tanzania \\ Email address: \\ matobola.mihale@gmail.com
}

\section{To cite this article:}

Matobola Joel Mihale. Nitrogen and Phosphorus Dynamics in the Waters of the Great Ruaha River, Tanzania. Journal of Water Resources and Ocean Science. Vol. 4, No. 5, 2015, pp. 59-71.doi: 10.11648/j.wros.20150405.11

\begin{abstract}
This study assessed the levels of nitrogenous (ammonia, nitrite and nitrate) and phosphate compounds in the water column in the Great Ruaha River (GRR) in response to natural and human pressures. Water were sampled using Teflon capped plastic containers and analysed using standard methods. High levels of ammonia were observed in the Mtera dam and low in the GRR and its tributaries as well as at Ruaha Mbuyuni. Nitrite levels were observed only in Mswiswi and Luwosi tributaries in the upstream and in the Mtera and Ruaha Mbuyuni in the downstream. High levels of nitrite were observed in the Mtera dam probably due to increased microbial activity. Levels of nitrates were high in the Mtera dam and in the Mswiswi and Lunwa tributaries and low in the Little Ruaha, Ruaha Mbuyuni and in other tributaries. Nitrate levels were increasing from the tributaries to the main river and later decreasing at Ruaha Mbuyuni probably indicative of some changes in land cover, land use, soil type and groundwater level. Observed levels of phosphate followed an irregular pattern and were relatively were high probably due to anthropogenic activities and absence of $\mathrm{Ca}, \mathrm{Mg}, \mathrm{Al}$ and $\mathrm{Fe}$ minerals that can precipitate phosphate. Levels of nitrogen and phosphorus in the GRR were lower than the US EPA and Health Canada set standards, indicative of a natural source. Principal Component Analysis (PCA) indicate that the nitrite and ammonia are so closely related to each other than to nitrate, indicating probably that most nitrites originate from the nitrification of ammonia than the denitrification of nitrate. Similarly, nitrate and phosphate were observed in the same principal component clearly indicative of the same source, which could be fertiliser application in agricultural fields. However, increasing agricultural and livestock activities as aggravated by increasing human population pose a threat on the future dynamics of the nitrogen and phosphorus in the area.
\end{abstract}

Keywords: Nitrate, Ammonia, Nitrite, Phosphate, Great Ruaha River, Tanzania

\section{Introduction}

Nitrogen and phosphorus are the two key biogenic elements often controlling the overall primary production in aquatic systems. Nitrogen is a key building block in all life forms[1] and phosphorus plays a major role in biological molecules such as hormones, enzymes, proteins and vitamins[2].Nitrogen exist as a gas in the atmosphere (almost $80 \%$ ) and is not available for use by most organisms. For plants and animals to be able to use nitrogen, $\mathrm{N}_{2}$ gas must first be converted to more chemically available forms [1] through nitrogen fixation, or chemical manufacture of ammonia. Ammonia then undergoes a series of reactions that consequently produce nitrate. For example, urea is hydrolysed to ammonium $\left(\mathrm{NH}_{4}^{+}\right)$under natural chemical process. Then, Nitrosomonas bacteria convert ammonium to nitrite $\left(\mathrm{NO}_{2}^{-}\right)$which is rapidly converted to nitrate $\left(\mathrm{NO}_{3}^{-}\right)$by
Nitrobacter species. Nitrate and ammonium can then be taken up by plants or used by other soil organisms. The plants are later consumed by animals to build their body tissues (meat, milk, wool). Animal manure, sewage sludge, crop residues, and roots add organic nitrogen materials through mineralisation to give ammonium, which is further transformed to nitrate [1] as shown in Fig. 1.

Phosphorus is released into the environment through weathering of minerals [4]. In aquatic systems, phosphorus originates naturally from the dissolution of phosphate minerals and mineralisation of algae. Anthropogenically, phosphorus originates from sewage discharges, industrial effluents, as well as diffuse inputs from grazing and agricultural land. While phosphorus may exist in either the dissolved, colloidal, or particulate form, the predominant species is orthophosphate in the mono-protonated ( $\mathrm{HPO}^{2-}$ ) or di-protonated $\left(\mathrm{H}_{2} \mathrm{PO}_{4}^{-}\right)$forms [5]. 
Phosphate is taken up by plants from soils, utilized by animals that consume plants, and returned to soils as organic phosphate residues. This organic phosphate is slowly released either as inorganic phosphate or incorporated into more stable organic materials and become part of the soil organic matter (Fig. 2). This mineralisation process is highly influenced by soil temperature and moisture. How much phosphorus is present in soil, and in what form will depend on the parent material from which the soil has been developed, amount of material that has been weathered, and land use.

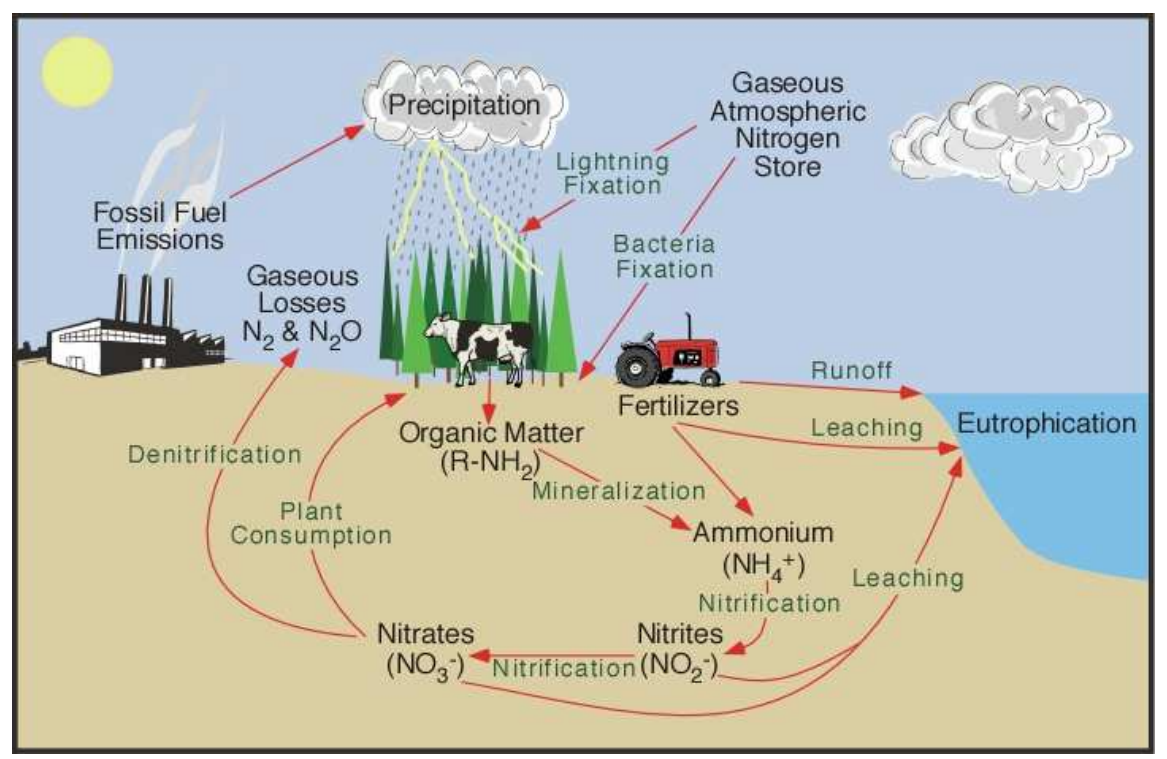

Figure 1. The Nitrogen Cycle [3].

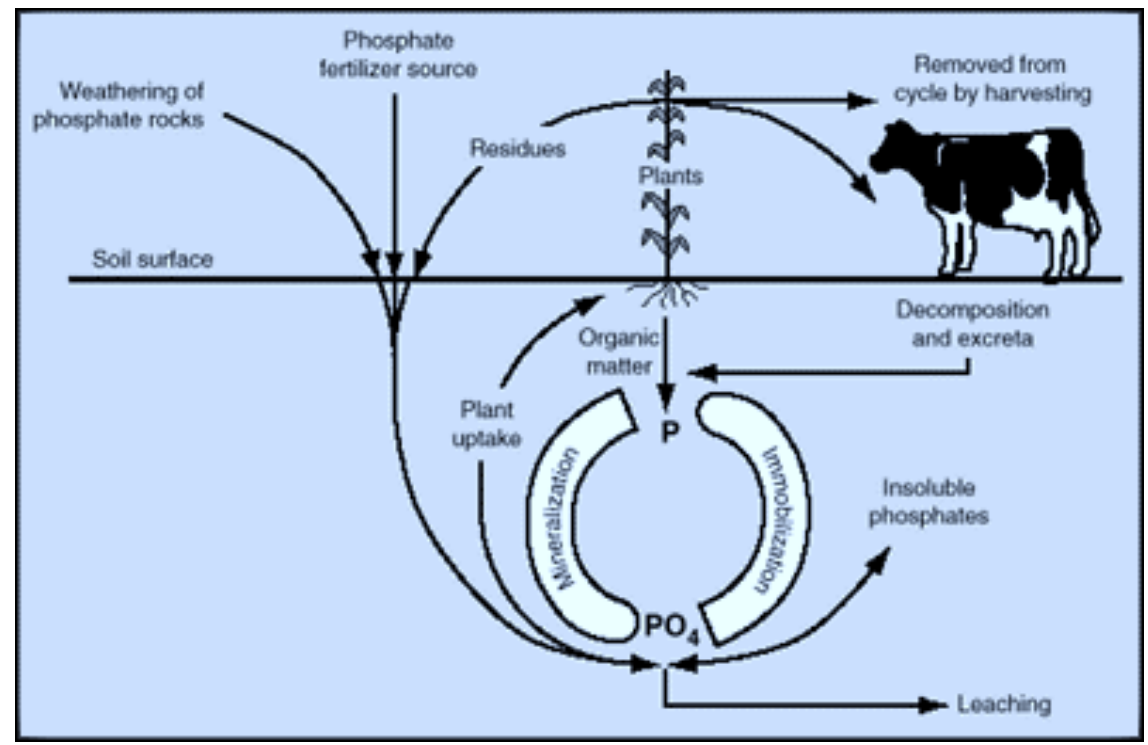

Figure 2. Phosphorus Cycle [6].

As fertilizer or manure comes in contact with the soil, moisture from the soil will begin dissolving the particle [9]. The presence of phosphate ions in solution is dependent on $\mathrm{pH}$ and is characterized by three equilibrium constants:

$$
\begin{aligned}
& \mathrm{H}_{3} \mathrm{PO}_{4} \rightleftharpoons \mathrm{H}_{2} \mathrm{PO}_{4}^{-}+\mathrm{H}^{+} \\
& \mathrm{H}_{2} \mathrm{PO}_{4}^{-} \rightleftharpoons \mathrm{HPO}_{4}^{-2}+\mathrm{H}^{+} \\
& \mathrm{HPO}_{4}{ }^{-2} \rightleftharpoons \mathrm{PO}_{4}^{-3}+\mathrm{H}^{+}
\end{aligned}
$$

Whereas the dominant phosphate species is orthophosphoric acid $\left(\mathrm{H}_{3} \mathrm{PO}_{4}\right)$ under acidic soil conditions, $\mathrm{PO}_{4}{ }^{3-}$ is the dominant species under alkaline soil conditions. However, $\mathrm{HPO}_{4}{ }^{2-}$ and $\mathrm{H}_{2} \mathrm{PO}_{4}{ }^{-}$dominate in the most natural conditions. The relative proportion of each form in a given area depends on the soil, vegetation, and land use characteristics [4].

Phosphorus loads from highlands to many aquatic systems have rapidly increased recently as a result of heavy fertilizer use and the demand to produce more food to meet the demand of the growing population. Converting wetlands to 
agricultural and urban lands decreased the capacity of existing wetlands to retain phosphorus. This has resulted in phosphorus enrichment of many lakes, rivers, estuaries, and coastal waters [4].

\subsection{Environmental Health Effects of Nitrogenous Compounds}

The nitrogenous species of environmental concern in water are $\mathrm{NH}_{4}{ }^{+}, \mathrm{NO}_{2}{ }^{-}$and $\mathrm{NO}_{3}{ }^{-}$. Ammonia that is released to the atmosphere tends to return to the plant-soil system relatively rapidly, thus increasing the nitrogen content of nearby vegetation. However, the bulk of atmospheric $\mathrm{NH}_{3}$ is converted to $\mathrm{NH}_{4}^{+}$, consuming some of the atmospheric acidity produced by human activities. But, high concentrations of ammonia may result in adverse effects such as leaf burn. Fine-particle ammonium aerosols can travel long distances and cause problems at a regional scale, impacting the water and air quality through wet deposition. $\mathrm{NH}_{3}, \mathrm{NO}_{2}{ }^{-}$are usually returned as dry deposition [9].

High concentrations of nitrate and nitrite may lead to eutrophication of the ecosystem due to over enrichment with nutrients [10]. Thus, in the presence of high nitrate levels, aquatic plants and algae are overproduced. This eventually causes settling of dead algae and macrophytes to the bottom of the water system, bacteria proliferation, depletion of dissolved oxygen, sunlight blocking, changes in colour and odours of water and the consequent elimination or reduction of photosynthesis by submerged aquatic vegetation. Exposure to nitrate concentrations in drinking water has been associated with increased incidences of hyperthyroidism (goitre), various cancers, birth defects and increased risk of central nervous system malformations in infants whose mothers consumed drinking water with high nitrate levels $[1,11]$. Furthermore, nitrate in food and drinking water is reduced to nitrite in the digestive system through bacterial and other reactions $[1,11]$. The nitrite may then oxidise the iron in the haemoglobin molecule to form methemoglobin [11], reducing the ability of the blood to effectively transport oxygen and carbon dioxide. The nitrite can be further reduced to $\mathrm{N}$-nitroso compounds (NOCs), which are carcinogenic and have been found to induce cancer in animals $[1,11]$.

\subsection{Environmental Health Effects of Phosphorus Compounds}

Phosphorus, despite being an essential element and nontoxic by itself, has low solubility and as a pollutant has detrimental effects on water quality at quite low concentrations. When soil particles with phosphorus are carried to a river, phosphorus will be contained in the sediment. When soil erosion occurs, more fine particles associated with the phosphorus are removed, causing the soil to be enriched with phosphorus [9]. When rivers are polluted with phosphorus, excessive growth of algae often results. High levels of algae reduce water clarity and can lead to decreased dissolved oxygen as the algae decays [7,10], loss of biodiversity, decreased recreational uses of waters, and the onset of harmful algal blooms. This is especially true in areas with intensive animal farming, where repeated manure applications have led to excessive accumulation of phosphorus in soils [1]. Once in the river these compounds are transformed through physico-chemical, microbial and biological processes, during their transfer along the aquatic continuum, i.e., from the river spring to estuaries, coastal waters and the ocean. These substances may have several negative effects on the aquatic ecosystem, threaten human health (e.g. poisoning, infection, etc) and impact the economical use of water resources (e.g. drinking water supply, fisheries, hydroelectric power, tourism, etc).

Superimposed by natural variability, the contemporary period is characterised by an ever-increasing utilization of materials, energy and space that emanate from the growing human population, industrial activity and intensive agricultural activities. As a result of severe increase of human impacts on aquatic ecosystems there has been an increasing flux of chemicals in the environment. Nutrient pollution is a significant problem worldwide, and recent reports from national and international organizations show that concentrations of nitrogenous and phosphorus compounds in water are increasing steadily. In developing countries like Tanzania water pollution caused by nutrients is still a serious problem as a result of increased urbanization, poor waste disposal and treatment procedures as well as intensive rural and urban agriculture. In the GRR, the nitrogen and phosphorus substances are brought to the river surface waters mainly due to leaching and erosion of agricultural soils [12]. Since water quality is not monitored systematically in Tanzania, the extent and severity of water pollution from nitrogen and phosphorus fertilisers and the consequences of this pollution is not known. However, data from the increasing use of fertilisers and the expansion of cropped area as well as the increased migration of population and livestock in the basin implies that this is a growing problem. This study was therefore intended to assess the water quality in the Great Ruaha River by determining the nutrient levels in the water column in response to natural and human pressures.

\section{Methodology}

\subsection{Study Area}

This study was conducted in the GRR Basin which is located within latitudes $7^{\circ} 41^{\prime}$ and $9^{\circ} 25^{\prime}$ south, and longitudes $33^{\circ} 40^{\prime}$ and $35^{\circ} 40^{\prime}$ east (Fig. 3). The Great Ruaha basin is characterised by hills and mountains consisting of granite and volcanic rocks and the plains consisting of alluvial fans and clay soils. The fans were developed by the depositions from the rivers disgorging from the highlands into the plains. The plains are surrounded by alluvial fans [14]. Rainfall distribution is variable and is influenced by topography. The average rainfall in this area is between $400 \mathrm{~mm}$ to $1,200 \mathrm{~mm}$ [15], with the most of it received in the highland areas (up to 
3,000m above sea level). The water from the Ruaha River and its tributaries forming the GRR flows with a mean flow of $140 \mathrm{~m}^{3} / \mathrm{s}$ [16]. The mean daily maximum and minimum temperature range from $28^{\circ} \mathrm{C}$ to $32^{\circ} \mathrm{C}$ and $9.5^{\circ} \mathrm{C}$ to $19.5^{\circ} \mathrm{C}$, respectively.

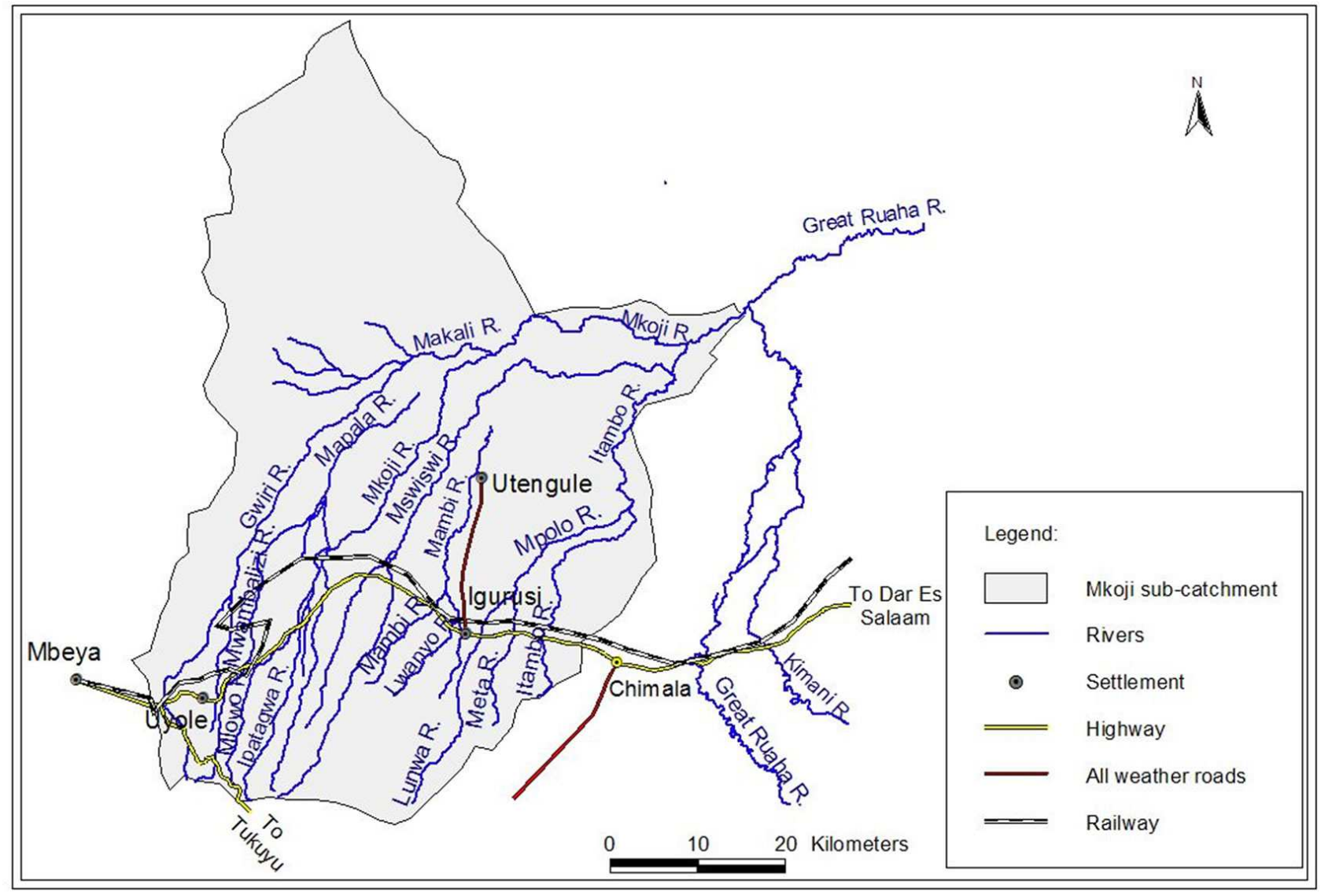

Figure 3. The Map showing the Great Ruaha River and the tributaries as adopted from [13].

The Basin is subjected to continuous change in the population trends as a result of migration and birth. Searching for pastures for livestock keepers from Hanang, Shinyanga, Mwanza, Tabora and Arusha has increased the population influx. The population growth has affected the resource base within the catchment leading to increase demand in the use of resources such as arable land, food and water [14]. The main socio-economic activities in the basin are agriculture and livestock keeping. Agriculture, which is both rain-fed and irrigated has attracted a large population (up to 90\%) in the catchment [14] where paddy, maize, beans and irish potatoes are grown as food crops and pyrethrum, vegetables, sunflower, coffee, tea and sugarcane are grown as commercial crops [14,17]. Various fertilisers are applied in the catchment. Inorganic fertilisers applied in the area include Calcium Ammonium Nitrate, CAN, [17,18,20], NitrogenPhosphorus-Potassium, NPK, [17,18], Urea [17,18,19,20], Triple super phosphate, TSP [18], Diammonium Phosphate, DAP, [19,20] and Sulphate of Ammonia, SA [20]. Some farmers use organic manure in their farms [19,21]. Livestock keeping is common in the basin and involves local and migrant livestock keepers where cattle, goats, donkeys and sheep are kept [14]. These livestock graze in the riverbanks, in Ihefu and Ifushiro swamps [16]. There is also mining of stone aggregates, sand, murram and soil for preparing burnt bricks [14] that take place near the riverbanks. Timber and logging from soft wood (Cyprus wood), pine, and eucalyptus and from the few indigenous species in the area has contributed to environmental degradation [14]. Wastewater from municipalities and industries within the basin are discharged into receiving water bodies with little or no treatment. For example, Iringa urban town discharges raw sewage into the GRR [23]. Nutrients from fertilisers applications during agricultural activities as well as from soil erosion add to the nutrient load reaching the river.

\subsection{Data Collection and Sampling}

Sampling was done in June 2008 in the Great Ruaha tributary rivers along the Makambako - Mbeya road on the upstream, Mtera dam and at Mbuyuni Bridge along the Morogoro - Iringa road on the downstream (Fig.3). Water samples were collected from pre-selected representative sites within the river basin (Table 1).

Table 1. Description of the water sampling points in the Great Ruaha River.

\begin{tabular}{lll}
\hline S/N & Sampling Site & Description of the Sampling Site \\
1 & Mswiswi river & $\begin{array}{l}\text { The river is very rock with some few debris } \\
\text { from trees }\end{array}$ \\
\hline
\end{tabular}




\begin{tabular}{|c|c|c|}
\hline $\mathbf{S} / \mathbf{N}$ & Sampling Site & Description of the Sampling Site \\
\hline 2 & Mambi river & The river is rocky with very little sediments. \\
\hline 3 & Lusowi river & The river is rocky with very few debris \\
\hline 4 & Lunwa river & $\begin{array}{l}\text { The river is rocky and its water are used for } \\
\text { drinking }\end{array}$ \\
\hline 5 & Meta river & The river is surrounded with bamboo trees \\
\hline 6 & Chimala river & $\begin{array}{l}\text { The river is rocky. Whereas the upstream is } \\
\text { used for washing clothes and drinking, the } \\
\text { downstream is a dumping site for saw dusts. } \\
\text { Some sewage effluents from the town are } \\
\text { emptied directly into the river }\end{array}$ \\
\hline 7 & $\begin{array}{l}\text { The Great } \\
\text { Ruaha river }\end{array}$ & The river is very steep \\
\hline 8 & Kimani river & The river has few debris from bamboo trees \\
\hline 9 & Igawa river & $\begin{array}{l}\text { The river is rocky; people do bath and livestock } \\
\text { drink the river water; cow dung and debris from } \\
\text { plants were observed }\end{array}$ \\
\hline 10 & Mbarali & $\begin{array}{l}\text { Water samples were taken near estate just } \\
\text { afterthe water comes out the farms Samples } \\
\text { were taken just before water from farm enters } \\
\text { the Mbarali river. Water is used for washing } \\
\text { clothes and drinking }\end{array}$ \\
\hline 11 & $\begin{array}{l}\text { Little Ruaha } \\
\text { river }\end{array}$ & $\begin{array}{l}\text { Sample taken at the bridge near Ipogolo; people } \\
\text { bath, wash clothes, defecate and urinate on the } \\
\text { river banks }\end{array}$ \\
\hline 12 & Mtera dam & $\begin{array}{l}\text { Sample taken between the tunnel mouth and the } \\
\text { barrier bridge, south of the barrier bridge and at } \\
\text { the dam gate on Iringa side. Water for domestic } \\
\text { purposes and livestock }\end{array}$ \\
\hline 13 & $\begin{array}{l}\text { Ruaha } \\
\text { Mbuyuni }\end{array}$ & $\begin{array}{l}\text { Sample taken at the new bridge. Water from the } \\
\text { river bank are used for bathing, washing clothes } \\
\text { and for livestock use. }\end{array}$ \\
\hline
\end{tabular}

Water samples for analysis of ammonia, nitrite, nitrate and phosphate (nutrients) were taken using Teflon capped plastic containers. Since the streams are generally shallow, samples were taken manually from the banks or from shallow spots in the stream by simply immersing the bottle in the water. Due to distance between the field and laboratory, all samples for ammonia analyses were preserved by addition of concentrated $\mathrm{H}_{2} \mathrm{SO}_{4}(2 \mathrm{~mL})$ to maintain a $\mathrm{pH}<2$. All water samples were later stored in cool box at $4^{\circ} \mathrm{C}$ until brought into the laboratory. In the laboratory, the samples were stored in the refrigerator at $4^{\circ} \mathrm{C}$ until analysis. The samples were analysed immediately within 7 days (less than 48 hours for nitrates and phosphates). Samples for nitrites and ammonia were analysed without filtration. However, samples for nitrate and phosphate determinations were filtered with 0.45 $\mu \mathrm{m}$ filters prior to analysis.

\subsection{Determination of Nutrient Levels in the Samples}

Water samples for nutrients were analysed using standard methods as described elsewhere [23], [24]. Identification of the nutrients was done using UV-VIS spectrophotometer as briefly described below. Quantification was done using the Beer-Lambert' equation and expressed in $\mathrm{mg} / \mathrm{L}$.

\subsubsection{Analysis of Ammonia}

Ammonia in water exists in the equilibrium with its ion, $\mathrm{NH}_{4}^{+}$, either as a base or an acid. As a base, ammonia exists in equilibrium with ammonia ion by the equation:

$$
\mathrm{NH}_{3}+\mathrm{H}_{2} \mathrm{O} \rightleftharpoons \mathrm{NH}_{4}^{+}+\mathrm{OH}^{-}-\cdots-
$$

Similarly, it can exist as an acid by the equation:

$$
\mathrm{NH}_{4}^{+}+\mathrm{H}_{2} \mathrm{O} \rightleftharpoons \mathrm{NH}_{3}+\mathrm{H}_{3} \mathrm{O}^{+} \ldots
$$

The amount of ammonia, as indicated by the equations above is influenced by temperature (through its $\mathrm{pK}_{\mathrm{a}}$ ) and $\mathrm{pH}$.

Ammonia reacts with hypochlorite and salycilate ion in alkaline solution to form green-blue colour (indophenol blue) in presence of nitroprusside catalyst [23].

$$
\mathrm{NH}_{3}+\mathrm{OCl}^{\ominus} \longrightarrow \mathrm{NH}_{2} \mathrm{Cl}+\stackrel{\ominus}{\ominus}
$$

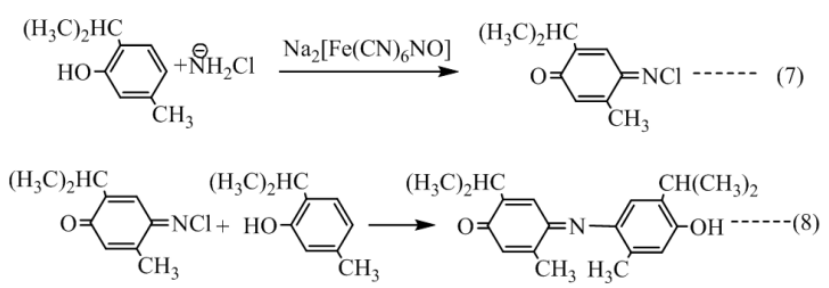

Addition of citrate compound precipitates $\mathrm{Mg}$ and $\mathrm{Ca}$ and thus eliminates interference. This reaction is conducted at room temperature with $\mathrm{pH}$ maintained within $\mathrm{pH} 4$ to 9 [23].

Sodium nitroprusside $(0.2 \mathrm{~g})$ and Sodium salycilate $(18 \mathrm{~g})$ were weighed separately and dissolved together in an Erlenmeyer flask containing distilled water $(100 \mathrm{~mL})$. Tri sodium citrate dihydrate $(100 \mathrm{~g})$ and $\mathrm{NaOH}(10 \mathrm{~g})$ were weighed and dissolved together in distilled water $(500 \mathrm{~mL})$. The hypochlorite solution was prepared by dissolving dichloro-sodiumcyanurate-dihydrate $(0.58 \mathrm{~g})$ in distilled water $(100 \mathrm{~mL})$. The citrate solution $(100 \mathrm{~mL})$ and dichlorosodiumcyanurate-dihydrate solution $(25 \mathrm{~mL})$ were mixed immediately before use. Standard ammonia stock solution was prepared by dissolving ammonia chloride $(0.3819 \mathrm{~g})$ in distilled water (1L) forming a stock solution of $0.1 \mathrm{~g} / \mathrm{L} \mathrm{NH}_{4}$ $\mathrm{N}$. Other working solutions were derived by dilution of the stock solution.

Fifty $(50) \mathrm{mL}$ of the sample in triplicate were placed in a $100 \mathrm{ml}$ Erlenmeyer flask. Then, phenolic solution $(2 \mathrm{~mL})$ was added and mixed. Later, hypochlorite solution $(2 \mathrm{~mL})$ was added and mixed thoroughly. The sample and the reagents were allowed to react for 90 minutes in the dark before its absorbance was measured in the spectrophotometer at $690 \mathrm{~nm}$. Blank samples were prepared using distilled water for zero adjustment of the spectrophotometer. Calibration curve was prepared by making a series of standards with 5 different concentrations in a proper range derived from the ammonia working solution. A plot of concentration versus measured absorbance resulted to a straight line that enabled the calculation of the linear regression factor (f) from calibration curve. Concentrations of ammonia in the water samples were calculated as follows:

$$
\mathrm{C}(\mathrm{mg} / \mathrm{L} \mathrm{NH} 4-\mathrm{N})=f x A
$$

where $\mathrm{C}=$ Concentration of $\mathrm{NH}_{4}-\mathrm{N}$ (in $\mathrm{mg} / \mathrm{L}$ ) in the sample, 
A $=$ measured absorbance in water sample, $f=$ factor from linear regression.

Sensitivity was improved by replacing a cuvette of $1 \mathrm{~cm}$ with $5 \mathrm{~cm}$ light path, and the calculation of concentration became:

$$
\mathrm{C}\left(\mathrm{mg} / \mathrm{L} \mathrm{NH}_{4}^{-}-\mathrm{N}\right)=\frac{(f x A)}{s}
$$

wheres $=$ thickness of cuvette $(1$ or $5 \mathrm{~cm})$

\subsubsection{Analysis of Nitrite}

Determination of nitrite in water is based on the reaction of nitrite with an aromatic amine leading to form a diazonium compound, which couples with a second aromatic amine. This azo dye is then quantified by spectrophotometry. In this method, sulphanilamide hydrochloride is used as the amino compound, where nitrite ions react with the sulphanilamide to form a diazo compound.

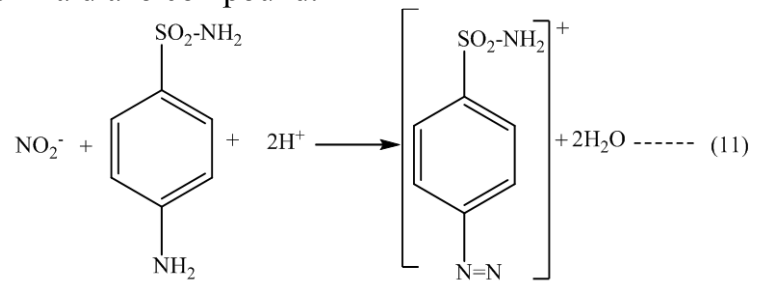

Then, the diazonium compound is coupled with $\mathrm{N}-(1-$ naphthyl)-ethylenediaminedihydrochloride(NEDD) in acidic conditions (strictly $\mathrm{pH}<2$ ) to produce a final pink-coloured complex that is quantified by spectrophotometry.

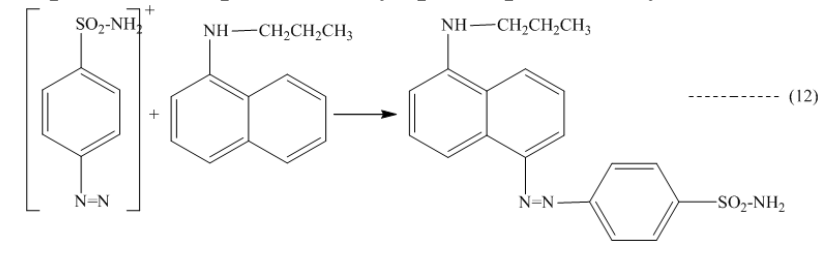

The sulphanilamide reagent was prepared by dissolving crystalline sulphanilamide $\left(\begin{array}{ll}10 & \mathrm{~g}\end{array}\right)$ in concentrated hydrochloric acid $(100 \mathrm{~mL})$ and then moderately heated to accelerate the dissolution. After cooling, the solution was made up to a $1 \mathrm{~L}$ with distilled water and stored in the dark $<8{ }^{\circ} \mathrm{C}$. NEDD reagent was prepared by dissolving the amine dihydrochloride $(0.5 \mathrm{~g})$ in distilled water $(500 \mathrm{~mL})$ and the solution stored in a brown bottle at $<8{ }^{\circ} \mathrm{C}$. Standard nitrite stock solution was prepared by dissolving anhydrous sodium nitrite $(2.482 \mathrm{~g})$ in distilled water $(1 \mathrm{~L})$. Working solutions of $\mathrm{NO}_{3}-\mathrm{N}$ were obtained by diluting the stock solution.

Determination of nitrite was done immediately due to high bacterial activity that may rapidly produce nitrite in the sample, hence producing erroneous results. A sample (50 $\mathrm{mL}$ ), with or without prior filtration, was transferred into a reaction bottle (100 $\mathrm{mL}$ volumes) and sulphanilamide regent $(1 \mathrm{~mL})$ was added. After mixing and about $1 \mathrm{~min}$ of reaction time, NEDD reagent $(1 \mathrm{~mL})$ was added. The flask was shaken and the azo dye was allowed to develop for $20 \mathrm{~min}$. The absorbance was measured at $540 \mathrm{~nm}$ within $1 \mathrm{~h}$ after the addition of the reagents.
Blank samples were prepared using distilled water for zero adjustment of the spectrophotometer. Calibration curve was prepared by making a series of standards with 5 different concentrations in a proper range derived from the nitrite working solution. A plot of concentration versus measured absorbance resulted to a straight line that enabled the calculation of the linear regression factor (f) from calibration curve. Concentrations of nitrite in the water samples were calculated as follows:

$$
\mathrm{C}\left(\mathrm{mg} / \mathrm{L} \mathrm{NO}_{2}^{-}-\mathrm{N}\right)=f x A
$$

where $\mathrm{C}=$ Concentration of $\mathrm{NO}_{2}{ }^{-}-\mathrm{N}$ (in $\mathrm{mg} / \mathrm{L}$ ) in the sample, $\mathrm{A}=$ measured absorbance in water sample, $\mathrm{f}=$ factor from linear regression

Sensitivity was improved as in section 2.3.2.

\subsubsection{Analysis of Nitrates}

Nitrate ions react with 2,6-dimethylphenol to form 4-nitro2,6-dimethylphenol in presence of sulphuric and phosphoric acids.<smiles></smiles>

High content of organic compounds, especially aromatic compounds are reduced by sulphuric acids resulting in a yellow colour interfering with analysis. As a result, filtration and sometimes addition of amidosulfonic acid is necessary [23]. The coloured phenolic compound is further quantified by spectrophotometry.

Solutions for the analysis of nitrates were prepared as follows: Solution 1 was prepared by dissolving 2,6dimethylphenol $(1.2 \mathrm{~g})$ in acetic acid $(1 \mathrm{~L})$. Solution 2 was prepared by mixing sulphuric and phosphoric acids in a 1:1 ratio. i.e. 1 volume of sulphuric acid is mixed with 1 volume of phosphoric acid. Standard nitrate stock solution was prepared by dissolving dry potassium nitrate $(0.722 \mathrm{~g})$ in distilled water $(1 \mathrm{~L})$. Working solutions of $\mathrm{NO}_{3}-\mathrm{N}$ were obtained by diluting the stock solution.

To a filtered sample $(5 \mathrm{~mL})$ in an Erlenmeyer flask (100 $\mathrm{ml})$, amidosulfonic acid $(50 \mathrm{mg})$ was added and left for 10 minutes. Then, solution $2(40 \mathrm{~mL})$ was added followed by solution $1(5 \mathrm{~mL})$. The reaction mixture is left to stand for 10 minutes. The absorbance of the resulting solution was measured at $234 \mathrm{~nm}$ in a cuvette prior rinsed with solution 2.Blank samples were prepared using distilled water for zero adjustment of the spectrophotometer. Calibration curve was prepared by making a series of standards with 5 different concentrations in a proper range derived from the nitrate working solution. A plot of concentration versus measured absorbance resulted to a straight line that enabled the calculation of the linear regression factor (f) from calibration curve. Concentrations of nitrate in the water samples were calculated as: 


$$
\mathrm{C}(\mathrm{mg} / \mathrm{L} \text { NO3--N) }=f x A
$$

where $\mathrm{C}=$ Concentration of $\mathrm{NO}_{3}{ }^{-} \mathrm{N}$ in $\mathrm{mg} / \mathrm{L}$ in the sample, $\mathrm{A}$ $=$ measured absorbance in water sample, $\mathrm{f}=$ factor from linear regression.

Sensitivity was improved as in section 2.3.2.

\subsubsection{Phosphate Analysis}

Analysis of phosphorus in water is based on the photometric measurement of 12-phosphormolybdate or the phosphormolybdenum blue species produced when phosphormolybdate is reduced [5]. Under acid conditions, orthophosphate ions react with molybdate ions in presence of antimony catalyst to form antimony-phosphorous-molybdate complex. This complex is then reduced to phosphormolybdate blue by ascorbic acid. The absorbance of the blue compound is easily determined with accuracy using spectrophotometer. Since nitrite concentrations over $1 \mathrm{mg} / \mathrm{L}$ generate bleaching of the complex colour, amidosulfonic acid was added to minimise the effect [23].

Solutions for the analysis of phosphates were prepared as follows: solution 1 was prepared by diluting sulphuric acid (192 $\mathrm{mL})$ distilled water $(300 \mathrm{~mL})$ while stirring. The solution is then kept cool at $20^{\circ} \mathrm{C}$. Ammonium molybdate solution (solution 2) was prepared by dissolving ammonium heptamolybdate-4-hydrate (16.7 g) in distilled water (200 $\mathrm{mL}$ ). Potassium antimony tartrate (solution 3) was prepared by dissolving potassium antimony (III) oxide tartrate hydrate $(0.471 \mathrm{~g})$ in distilled water $(100 \mathrm{~mL})$. Ascorbic acid was prepared by dissolving $\mathrm{L}(+)$ ascorbic acid $(20 \mathrm{~g})$ in distilled water $(300 \mathrm{~mL})$. A working mixed reagent was prepared by adding amidosulfonic acid $(1.33 \mathrm{~g} / 100 \mathrm{~mL})$ to solution 1 followed by solutions 2 and 3. Standard phosphate stock solution was prepared by dissolving potassium hydrogen phosphate $(4.3935 \mathrm{~g})$ in distilled water $(1000 \mathrm{~mL})$. Working solutions of the phosphate standard were prepared by diluting the stock solution.

To a filtered water sample $(50 \mathrm{~mL})$ in the Erlenmeyer flask $(100 \mathrm{~mL})$, mixed reagent $(1.5 \mathrm{~mL})$ was added. Then, ascorbic acid solution $(0.75 \mathrm{~mL})$ was added and the resulting mixture was left to stand for 6 minutes. The absorbance of the resulting solution was measured at either 800 or $890 \mathrm{~nm}$. Blank samples were prepared using distilled water for zero adjustment of the spectrophotometer. Calibration curve was prepared by making a series of standards with 5 different concentrations in a proper range derived from the phosphate working solution. A plot of concentration versus measured absorbance resulted to a straight line that enabled the calculation of the linear regression factor (f) from calibration curve. Concentrations of phosphates in the water samples were calculated by:

$$
\mathrm{C}(\mathrm{mg} / \mathrm{L} \mathrm{PO} 4-3)=f x A
$$

where $\mathrm{C}=$ Concentration of $\mathrm{PO}_{4}{ }^{-3}$ in $\mathrm{mg} / \mathrm{L}$ in the sample, $\mathrm{A}=$ measured absorbance in water sample, $\mathrm{f}=$ factor from linear regression

Sensitivity was improved as in section 2.3.2.

\subsection{Analytical Quality Assurance}

The analytical as well as quality assurance and quality control, QA/QC, procedures were used throughout the analytical steps. Blanks and recovery tests were determined to check for the accuracy of the method and reliability of the results obtained. Blanks were subjected to similar treatments like normal samples during the analytical process.

\subsection{Data Analysis}

Means and standard deviations (STD) of the data obtained were appropriately determined. Further analysis using Pearson Correlation, Principal Component Analysis (PCA) and Student's t-test were performed. PCA was used to evaluate differences and elucidate the relationships between various parameters. Pearson correlation and PCA were performed using Statistical Package for Social Sciences (SPSS, v. 20) for Windows and t-test was determined using Microsoft excel 2007. The findings were presented in form of tables and figures as shown in the next section.

\section{Results and Discussion}

\subsection{Rainfall Trend}

The mean annual rainfall data in the Great Ruaha basin are given in Fig.4. The rainfall data showed an irregular trend with most rainfall data being above the average value of 600 $\mathrm{mm}$ for the period between 1958 and 1996. However, from 1997 to 2004 there has been a decreasing trend to $320 \mathrm{~mm}$ in 2000 and then increasing to $770 \mathrm{~mm}$ in 2004 (Fig.4). Reports have shown that the average rainfall for year 2013 from two stations in the Great Ruaha basin was $445.4 \mathrm{~mm}$ at Msembe and $741.9 \mathrm{~mm}$ at Iringa Maji, indicating a decrease change of $88.4 \%$ at Msembe and increase change of $106 \%$ at Rufiji Maji [15]. This fluctuating rainfall in recent years and could have an impact on the nutrient dynamics in the GRR.

\subsection{Levels of Nutrients in the Great Ruaha River}

\subsubsection{Ammonia}

Observed levels of ammonia were low in the GRR and tributaries and high at the Mtera area, probably due to cumulative effect. The levels at Ruaha Mbuyuni was more or less the same as the levels in the tributaries (Fig. 5). Relatively high levels of ammonia in aqueous environments are not usually observed due to the nitrification process by Nitrosomonas species to form nitrite and then by Nitrobacter species that convert the nitrite to nitrate [1]. The overall nitrification equation is:

$\mathrm{NH}_{4}^{+}+\mathrm{SO}_{2} \longrightarrow 2 \mathrm{H}^{+}+\mathrm{NO}_{3}^{-}+\mathrm{H}_{2} \mathrm{O}$ 


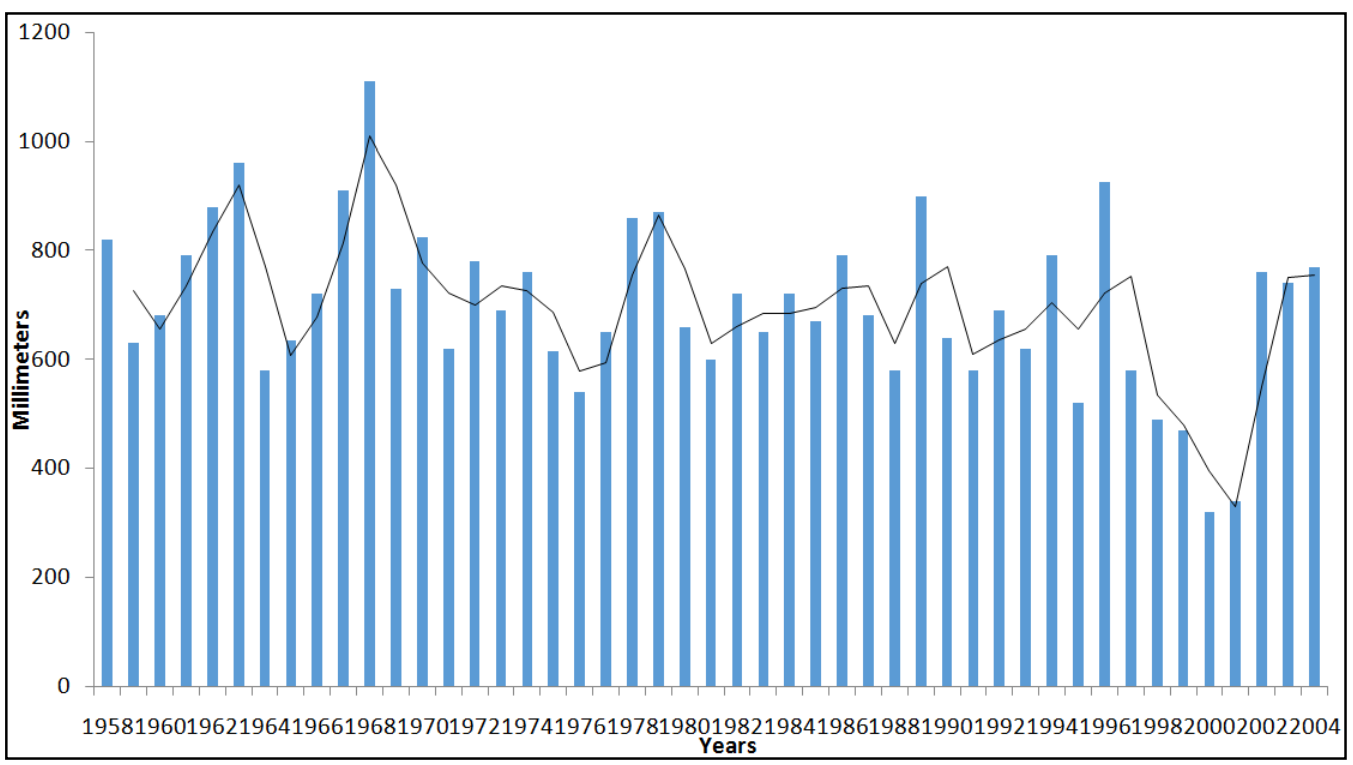

Figure 4. Mean annual rainfall data for the Great Ruaha Basin (1958 - 2004).

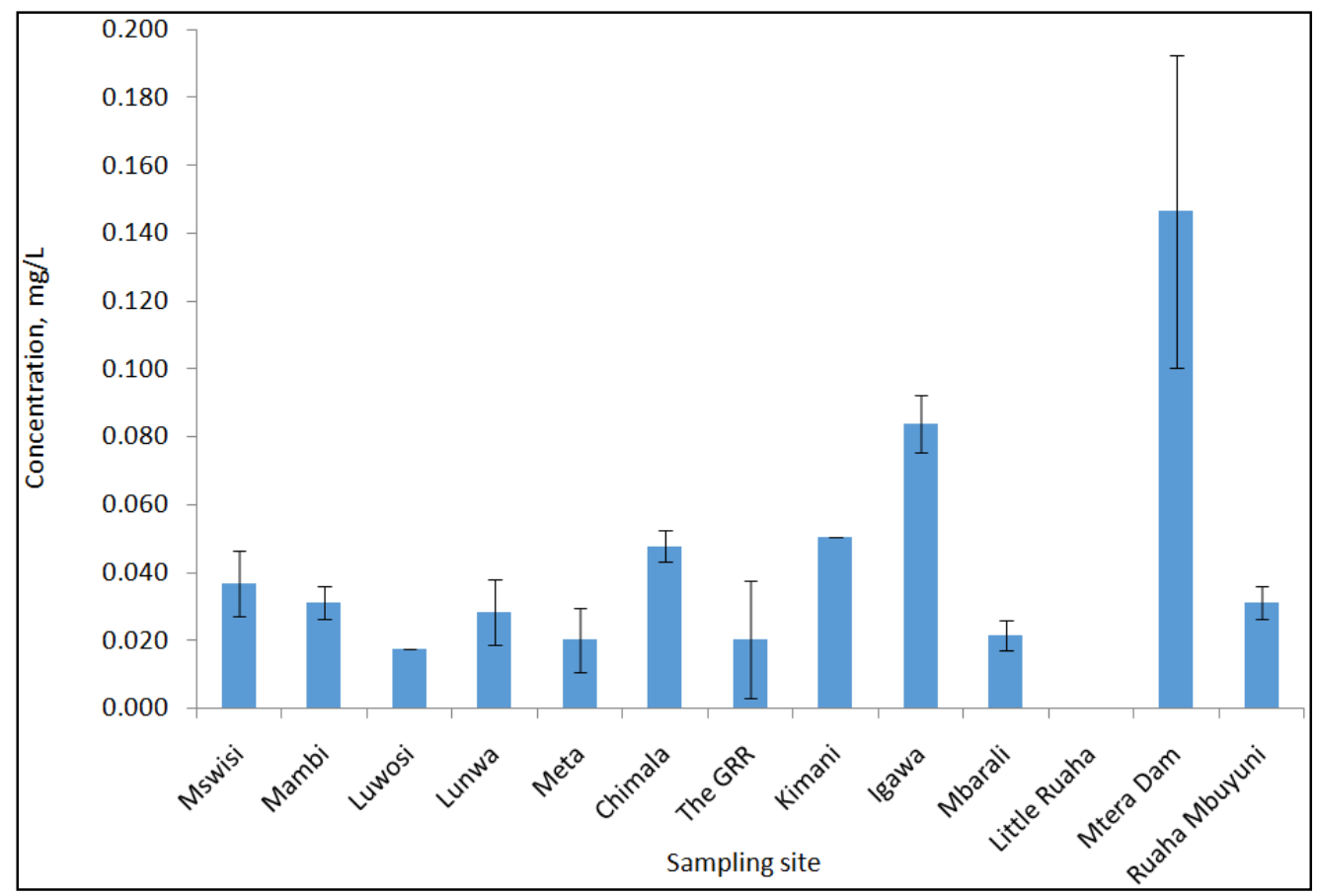

Figure 5. Concentration of $\mathrm{NH}_{3}-\mathrm{N}(\mathrm{mg} / \mathrm{L})$ in the Great Ruaha River and its tributaries.

Generally, the ammonia levels in rivers are less than 6 $\mathrm{mg} / \mathrm{L}$. In presence of good amount of oxygen, favourable temperature, favourable $\mathrm{pH}$ (acidic condition) and microbial population, the levels of ammonia in a given area will always be low [1]. The ammonia levels observed in the study were generally low as expected, despite the fact that levels in Mtera were slightly higher than in other stations. This is probably due to the favourable conditions for microbial growth in the area. Furthermore, volatility of ammonia increases with increasing temperature [9]. Therefore with the high temperatures of the tropical GRR, it is not surprising to observe low levels of ammonia in the area. The observed ammonia levels were generally lower than the set standard criteria of $0.05 \mathrm{mg} / \mathrm{L}$ [26] in the upstream and higher than the set value in the Mtera dam. The ammonia levels in the Mtera were even above $1.0 \mathrm{mg} / \mathrm{L}$, which is indicative of suspicious recent pollution from surrounding areas.

\subsubsection{Nitrite}

Nitrite levels were detected only in Mswiswi and Luwosi tributaries of the GRR in the upstream and in the Mtera and Ruaha Mbuyuni in the downstream (Fig.6). In other areas the levels were below the detectable amount. High levels were observed in the Mtera as compared to other sampling stations.

Nitrite occurs either in the reduction process of nitrate or in the conversion of ammonia to nitrate. Hence, in 
oxygenated surface water, there is little nitrite present and nitrite concentrations are generally below $0.5 \mathrm{mg} / \mathrm{L} \mathrm{NO}_{2}^{-}-\mathrm{N}$ because it is readily oxidised to nitrate. High concentrations of nitrite are usually linked to microbial activity, but they may also indicate polluted water [11]. The observed levels of nitrite were higher at the Mtera Dam and lower in river tributaries. This is indicative of the increased biological activities at the Mtera area particularly Nitrosomonas bacteria that tend to increase nitrite amount in the water. However, the high concentration levels observed in the Mtera samples were still below the recommended set values of $3 \mathrm{mg} / \mathrm{L}$ for nitrite in water, which is equivalent to $1 \mathrm{mg} / \mathrm{LNO}_{2}{ }^{-} \mathrm{N}$ [27].

\subsubsection{Nitrate}

Slightly high levels of nitrates were observed in the Mswiswi and Lunwa tributaries of the GRR. In other tributaries (Mambi, Meta, Chimala, Kimani, Igawa and Mbarali), the levels were low. The levels were even lower in the Little Ruaha but generally high in the Mtera dam and slightly low at Ruaha Mbuyuni (Fig. 7). This trend indicate that the levels were increasing from the tributaries to the main river as observed by the high concentrations of nitrate in the Mtera dam. However, there is a decrease at Ruaha Mbuyuni indicating some changes in land cover soil type, groundwater level and land use. High concentrations of nitrate are associated with carbonate-type soils, shallow groundwater, and increased use of the land for agriculture [11]. The high levels of nitrate in the GRR could be due to presence of carbonated soils as well as increased anthopogenic activities [28] i.e. agricultural use of the land. The observed levels of nitrate the Mswiswi and Lunwa Rivers and in the Mtera dam could be indicative of anthropogenic activities on the upstream of the River. Fortunately, the anthropogenic contribution of the pollutant is still not so large to pose any potential environmental impact.

Nitrate is the most common contaminant of water. When present, nitrate does not volatilise, and it is likely to remain in water until consumed by plants or other organisms. Because of its stability and solubility, elevated level of nitrate in water may also indicate the presence of other contaminants, microbial pathogens and pesticides [11]. While nitrate concentration in deep seawater and natural unpolluted groundwater is usually below $0.05 \mathrm{mg} / \mathrm{L} \mathrm{NO}_{3}{ }^{-}-\mathrm{N}$, the concentrations in shallow groundwater and surface streams range from less than $0.1 \mathrm{mg} / \mathrm{L} \mathrm{NO}_{3}{ }^{-} \mathrm{N}$ to $20 \mathrm{mg} / \mathrm{L} \mathrm{NO}_{3}{ }^{-} \mathrm{N}$ [27] depending on soil type, land use practices and depth. In areas of high anthropogenic impacts, the levels can be as high as $30 \mathrm{mg} / \mathrm{L} \mathrm{NO}_{3}{ }^{-}-\mathrm{N}$. This implies that although nitrate and nitrite are naturally occurring forms of nitrogen, elevated levels in aquatic systems usually result from human activities [11]. The observed nitrate levels in the GRR ranged from $0.01 \mathrm{mg} / \mathrm{L}$ at Meta River to $0.51 \mathrm{mg} / \mathrm{L}$ at Mswiswi River. The levels of nitrite and nitrate were both less than $1 \mathrm{mg} / \mathrm{L}$, indicating no agricultural contamination from either fertilisers or seepage [25]. The observed levels in the area are within the ranges of nitrates naturally occurring in surface water, indicative of a natural source. The United States Environmental Protection Agency (US EPA) and Health Canada have set a maximum (allowable) contaminant level (MCL) of $45 \mathrm{mg} / \mathrm{L}$ (equivalent to $10 \mathrm{mg} / \mathrm{L} \mathrm{NO}_{3}{ }^{-}-\mathrm{N}$ ) for nitrates in drinking water [1], [26]. The results indicate that $\mathrm{NO}_{3}{ }^{-} \mathrm{N}$ levels observed in the GRR are lower than the US EPA and Health Canada set standards.

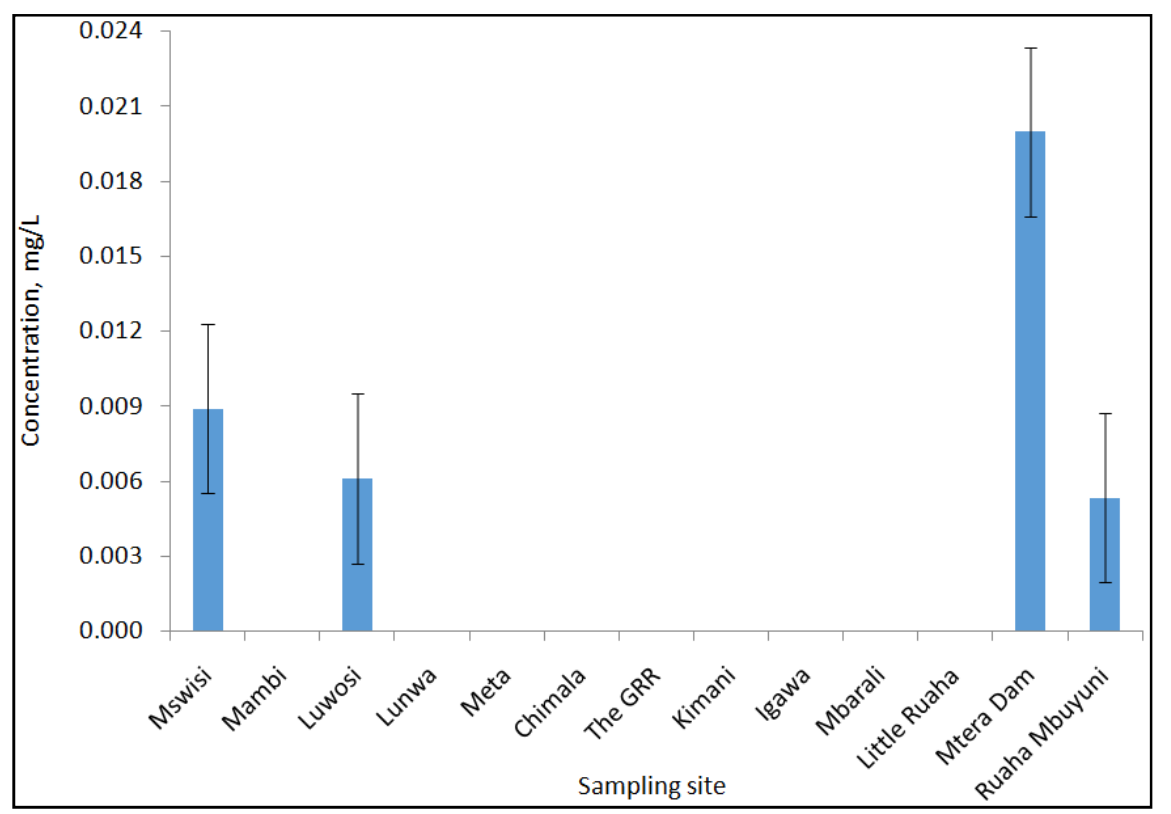

Figure 6. Concentration of $\mathrm{NO}_{2}^{-}-\mathrm{N}(\mathrm{mg} / \mathrm{L})$ in the Great Ruaha River and its tributaries. 


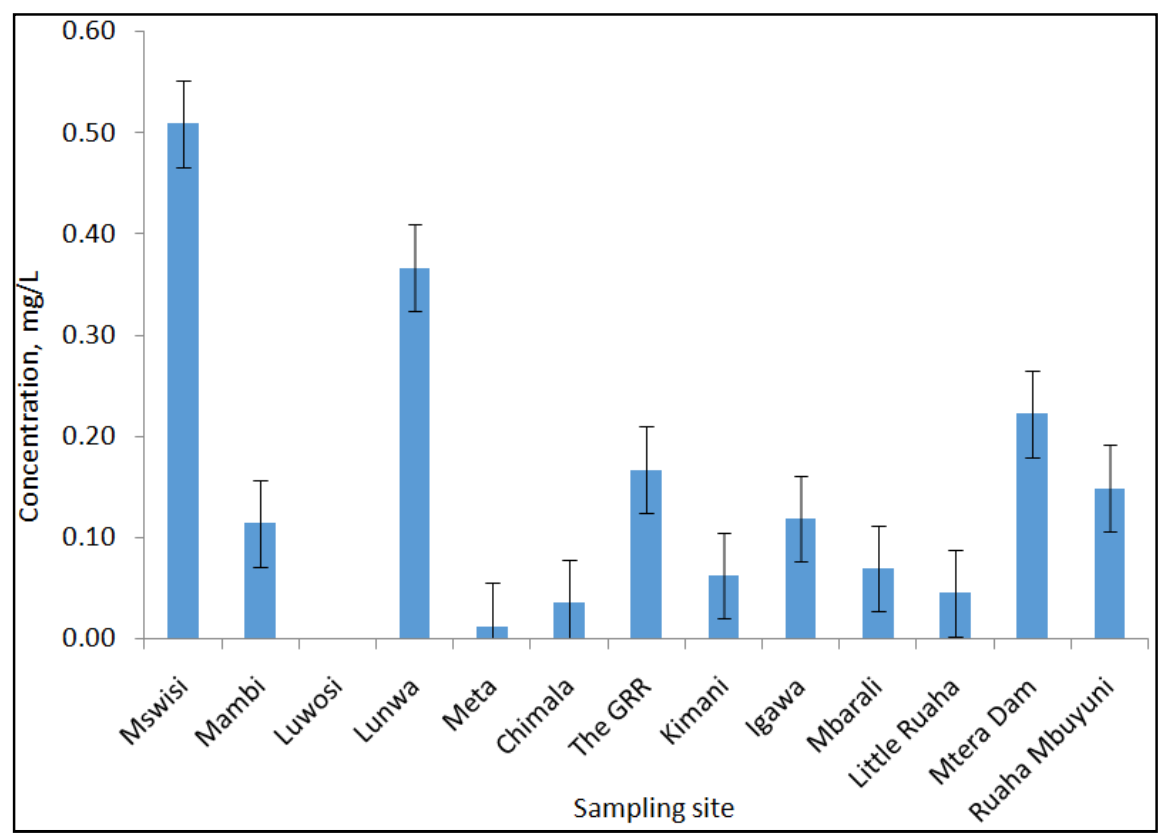

Figure 7. Concentration of $\mathrm{NO}_{3}^{-}-\mathrm{N}(\mathrm{mg} / \mathrm{L})$ in the Great Ruaha River and its tributaries.

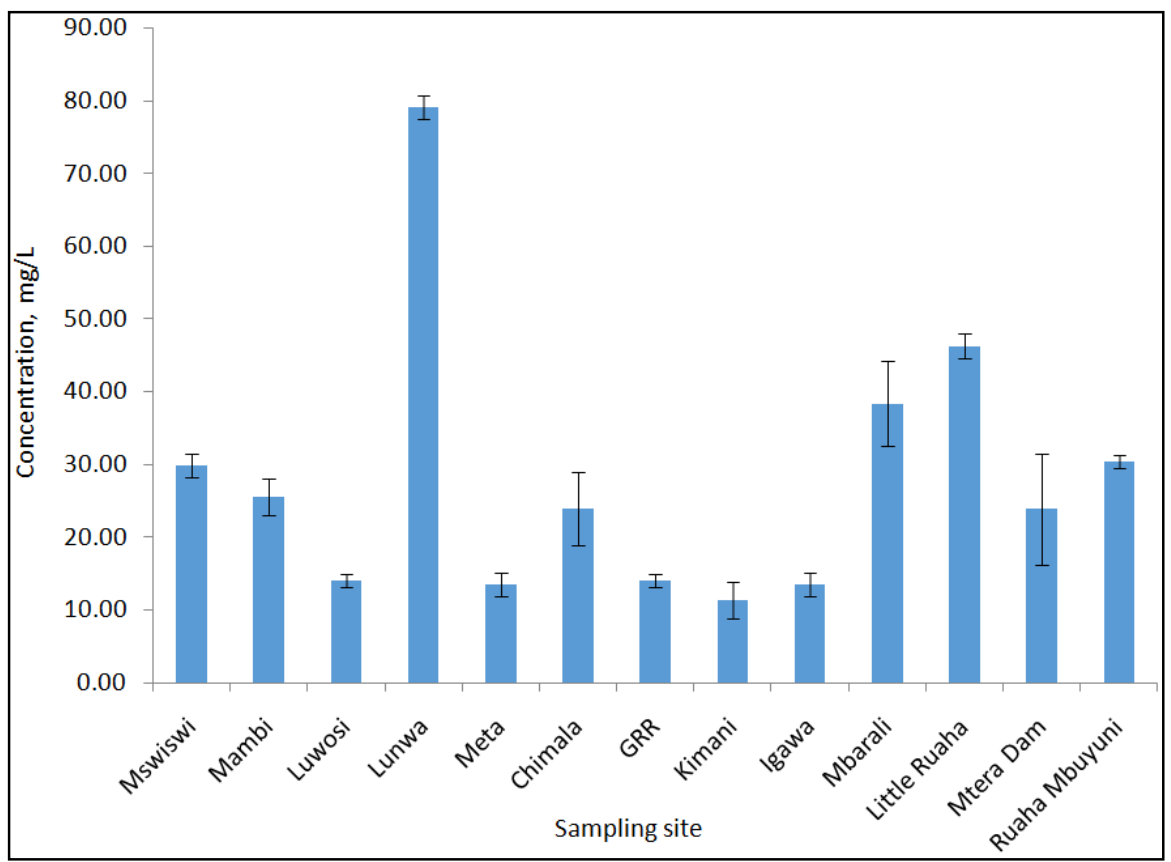

Figure 8. Concentration of phosphate $(\mathrm{mg} / \mathrm{L})$ in the Great Ruaha River and its tributaries.

The removal of dissolved forms of the nitrogenous compounds is regulated by various biogeochemical reactions in soil and overlying water column. The relative rates of these processes are affected by physicochemical and biological characteristics of the soil and water column as well as the organic substrates present [4]. Humans have a direct impact on nitrogen inputs to terrestrial systems mainly by increasing the productivity and area sown with addition of fertilisers and growing of $\mathrm{N}_{2}$-fixing legume crops and pastures. Anthropogenic sources of nitrate and nitrite include intensive use of chemical nitrogenous fertilisers, improper disposal of plant and animal waste, municipal and industrial wastewater discharge, sewage disposal systems and landfills. In the GRR, agriculture is the largest contributor to the pollution of water because of the use of nitrogen fertilisers and also because of the influx of livestock in the area, which produces a great amount of manure as observed in a similar study [11]. As a result of the increased anthropogenic pressures in the GRR, the levels of nitrogenous nutrients in water may pose a threat in the future.

\subsubsection{Phosphorus}

The observed phosphorus levels in the GRR and its tributaries followed an irregular trend. Highest phosphate levels of $79.11 \mathrm{mg} / \mathrm{L}$ were observed at the Lunwa River and 
lowest levels of $11.31 \mathrm{mg} / \mathrm{L}$ were observed at Kimani River (Fig. 8). Slightly higher levels were observed in Mbarali, Little Ruaha, Mtera and Ruaha Mbuyuni.

Many phosphate compounds are not very soluble in water; therefore, most of the phosphate in natural systems exists in solid form. However, soil water and surface water (rivers and lakes) usually contain relatively low concentrations of dissolved (or soluble) phosphorus [10]. Depending on the types of minerals in the area, bodies of water usually contain about $10 \mu \mathrm{g} / \mathrm{mL}$ or more of dissolved phosphorus as orthophosphate [7]. The observed levels in the GRR were higher than the expected values probably due to land use near the tributaries [7] and absence of $\mathrm{Ca}, \mathrm{Mg}, \mathrm{Al}$ and $\mathrm{Fe}$ minerals in the soil that can react with the phosphate in water forming solid compounds that are relatively available for plants [8]. In addition, there are probably favourable anaerobic (reducing) conditions that reduce the insoluble $\mathrm{Fe}^{3+}$ that can adsorb the phosphate to soluble $\mathrm{Fe}^{2+}$ thereby increasing the phosphate levels in the aqueous medium [25]. The observed high levels of phosphate in the waters of the GRR might be due to the reducing conditions that exist in the area.

\subsection{Nutrient Source Analysis by Principal Component Analysis (PCA)}

Multivariate analysis can be used to identify similarities and differences between nutrient pollutants in samples as a means to detect possible sources. In order to determine the relationship between nutrients, PCA after varimax rotation was employed. A principal component (PC) was considered significant when its eigenvalue was greater than 1 . The measured nutrient values were used as variables (total 4), with the concentrations of the nutrients in the different sampling stations as objects (total 64). The results of the PCA analysis are presented in Table 2. Based on the loading distribution of the variables, the PCA results indicated that the variables can be represented by two principal components that accounted for $79.3 \%$ of the total variance in the original data sets (Fig.9).

Table 2. Rotated Principal Component (PC) Matrix.

\begin{tabular}{lll}
\hline & \multicolumn{2}{l}{ Principal Component $(83.9 \%)$} \\
nitrite & PC 1 $(44.8 \%)$ & PC 2 $(39.1 \%)$ \\
Ammonia & $\mathbf{0 . 9 2 0}$ & 0.139 \\
Phophorus & $\mathbf{0 . 9 0 7}$ & -0.071 \\
nitrate & 0.192 & $\mathbf{0 . 8 9 1}$ \\
\hline
\end{tabular}

As we could expect, ammonia, nitrite and nitrate constituted one related group (PC 1), while the phosphate and nitrate formed the other group (PC 2). This clearly indicates that the sources of the ammonia and nitrite on one hand differ from that of phosphate and nitrate in the other. This is evidenced by the positive correlation between ammonia and nitrite $\left(\mathrm{r}^{2}=0.70, \mathrm{p}=0.01\right)$ and positive correlation between nitrate and phosphate $\left(r^{2}=0.55, p=0.03\right)$.

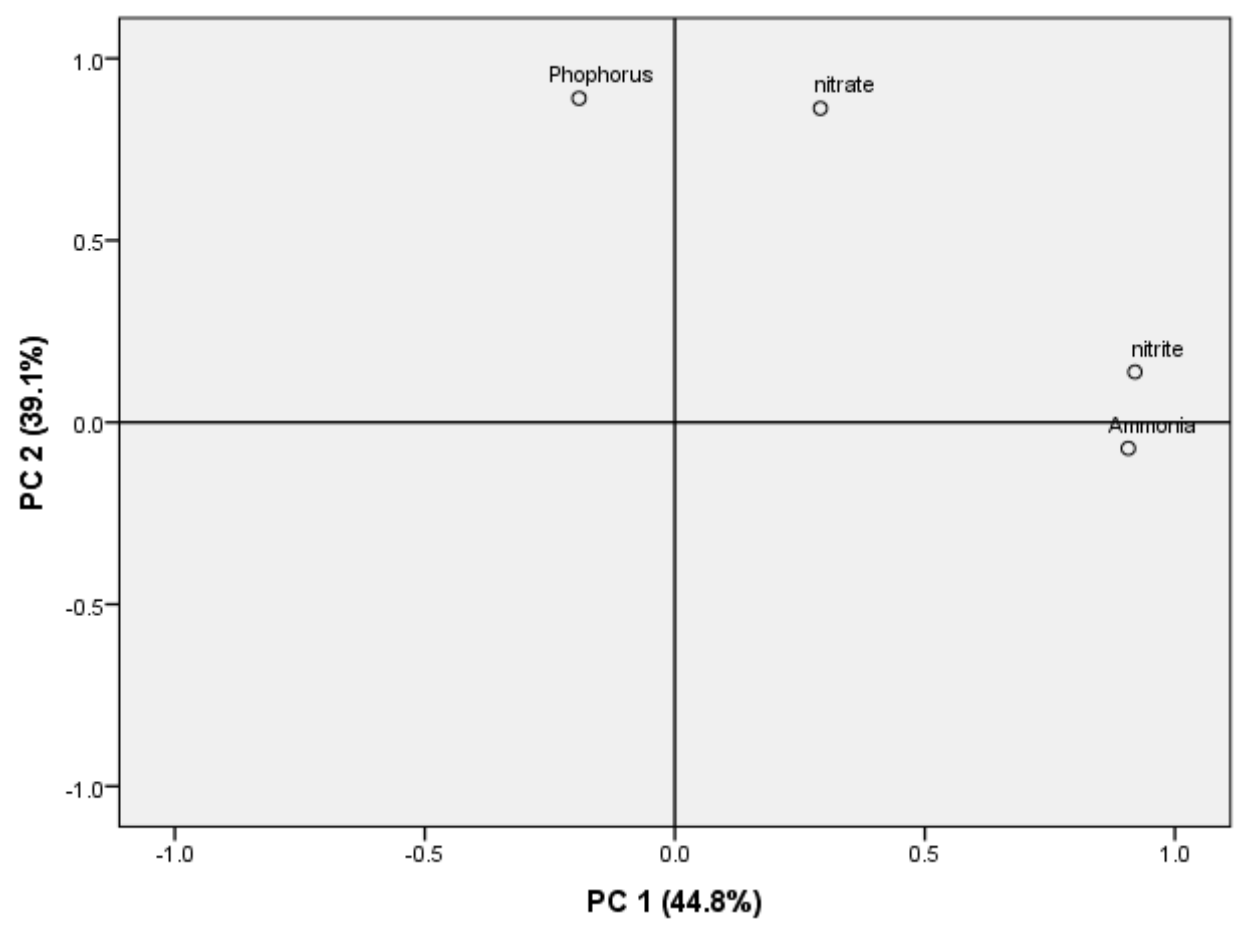

Figure 9. A two-dimensional score pot of the nutrients in the Great Ruaha River.

Fig. 9 clearly indicates that ammonia and nitrite have a common source, different from that of phosphorus and nitrate as expected. In addition, PCA indicate that the nitrite and ammonia are so closely related to each other than to nitrate, indicating probably that most nitrite originate from the nitrification of ammonia than the denitrification of nitrate. In addition, existence of nitrate and phosphate in the same PC clearly indicate that these nutrients have the same source. In the GRR, this could probably be fertiliser application in agricultural fields. 


\section{Conclusion}

Ammonia, nitrite, nitrate and phosphate nutrients in water from the GRR and its tributaries and their source have been determined.The findings have indicated that the nutrients in the basin originate from natural source. However, application of fertilisers in agriculture has been identified as a potential anthropogenic source in the future. As a result, increasing agricultural and livestock activities in the basin as aggravated by the increasing population can pose a threat on the future nutrient dynamics in the GRR basin as a whole.

\section{References}

[1] Berkowitz B., Dror, I., Yaron, B (2008), Contaminant geochemistry: transport and fate in the subsurface environment, Springer-Verlag Berlin Heidelberg.

[2] Bünemann, E. K and Condron L. M (2007). Phosphorus and sulphur cycling in terrestrial ecosystems in Marschner, $\mathrm{P}$ and Rengel, Z (Eds). Nutrient cycling in terrestrial ecosystems, Springer-Verlag Berlin Heldelberg.

[3] Fundamentals of physical geography (2nd Edition) Accessed on 20th November 2014 at http://www.physicalgeography.net/fundamentals/contents.html.

[4] Redd, R, and Delaune R. D., (2008). Biogeochemistry of wetlands, science and applications, Taylor and Francis Group, LLC, CRC Press.

[5] McKelvie, I.D (2000). Phosphates in Nollet L.M.L (Ed). Handbook of water analysis, food science and technology, CRC Press, Marcel Dekker, Inc.

[6] Phosphorus Nutrient Management. Accessed on 20th November 2014 at http://www.ctahr.hawaii.edu/mauisoil/c_nutrients02.aspx.

[7] Adeyemo, O.K., Adedokun, O.A., Yusuf, R.K., Adeleye, E.A., (2008). Seasonal changes in physico-chemical parameters and nutrient load of river sediments in Ibadan city, Nigeria, Global NEST Journal, Volume 10, No 3, pp 326-336.

[8] Busman, L., Lamb, J., Randall, G., Rehm, G and Schmitt, M (2009). The nature of phosphorus in soils: Phosphorus in the agricultural environment, ww-06795-GO, Regents of the University of Minnesota. Accessed at http://www.extension.umn.edu/distribution/cropsystem/DC67 95.html on 3rd June 2014.

[9] McNeill, A., and Unkovick, M., (2007). The Nitrogen cycle in the Terrestrial Ecosystems in Marschner, $\mathrm{P}$ and Rengel, $\mathrm{Z}$ (Eds). Nutrient cycling in terrestrial ecosystems, SpringerVerlag Berlin Heldelberg.

[10] Worsfold, P. J., Monbet, P. Tappin A. D., Fitzsimons, M. F., Stiles, D. A., McKelvie, I. D., (2008). Characterisation and quantification of organic phosphorus and organic nitrogen components in aquatic systems: A Review, Analytical ChimicaActa, Volume 624, 37-58.

[11] Oms, M. T., Cerdà, A and Cerdà, V (2000). Analysis of nitrates and nitrites in Nollet, L. M. L., (Ed.), Handbook of water analysis, food science and technology, CRC Press, Marcel Dekker, Inc.

[12] Beaudoin, N., Saad, J., Van Laethem, C., Maucorps, J.,
Machet, J.M. and Mary, B., (2005). Nitrate leaching in intensive arable agriculture in Northern France: effect of farming practices, soils and crop rotations. Agriculture, Ecosystem and Environment, 11:292-310.

[13] Mwakalila S (2011) Assessing the hydrological conditions of the Usangu Wetlands in Tanzania, Journal of Water Resource and Protection, Vol.3 (12),DOI:10.4236/jwarp.2011.312097.

[14] Sosovele, H., Ngwale, J.J., (2002). Socio-economic root causes of theloss of biodiversity in the Ruaha catchment area. Report submitted to WWF-TANZANIA. http://assets.panda.org/downloads/rcareportruaha.doc. Accessed on 23rd October 2014.

[15] Rufiji Basin Water Board (2013). Rufiji basin annual hydrological report - 2012/2013, Iringa, Tanzania.

[16] Kashaigili, J.J. and Rajabu, K.R.M (2003). Draft fact sheet on ecohydrology of Great Ruaha River, Raising irrigation productivity and releasing water for intersectoral needs (RIPARWIN): A DFID and IWMI - funded River Basin Management Research Project in Tanzania. http://www.iwmi.cgiar.org/Africa/files/RIPARWIN/05/ downl oads/Fact-Factsheet_EcoHyd_GRR.doc. Accessed on 22nd October 2014.

[17] URT -United Republic of Tanzania, Ministry of Agriculture and Food Security (2002). River basin management and smallholder irrigation project, smallholder irrigation improvement component: Initial environmental examination at Mapogoro irrigation scheme, Draft Paper, E968, Volume 11, Environmental cell unit http://wwwwds.worldbank.org/external/default/WDSContentServer/WDS P/IB/2004/07/26/000160016_20040726123351/Rendered/IND EX/E9680vol011.txt. Accessed on 22nd October 2014.

[18] URT - United Republic of Tanzania, Ministry of Agriculture and Food-Security (2003). River basin management and smallholder irrigation improvement project (RBMSIIP): Smallholder Irrigation Improvement Component: Ruanda Majenje Irrigation Scheme, Environmental Audit, Draft Report E968, Volume 5. Environmental Resources Consultancy, Consulting environmental conservation. Natural resources management and capacity building. http://wwwwds.worldbank.org/external/default/WDSContentServer/WDS P/IB/2004/07/26/000160016 20040726121644/Rendered/PD F/E9680vol05.pdf. Accessed on 24th October 2014.

[19] URT - United Republic of Tanzania, Ministry of Agriculture and Food-Security (2003). River basin management and smallholder irrigation improvement project (RBMSIIP): Smallholder Irrigation Improvement Component: Igomelo Irrigation Scheme, Environmental Audit, Draft Report E968, Volume 4. Environmental resources consultancy, consulting environmental conservation. Natural resources management and capacity building. http://wwwwds.worldbank.org/external/default/WDSContentServer/WDS P/IB/2004/07/26/000160016 20040726121315/Rendered/PD F/E9680vo104.pdf. Accessed on 24th October 2014.

[20] URT - United Republic of Tanzania, Ministry of Agriculture and Food Security (2003). River basin management and smallholder irrigation improvement project (RBMSIIP), Small holder irrigation improvement component; Nyamahana irrigation scheme: Environmental Audit, Draft Report E968, Volume 8, Environmental Resources Consultancy. http://www-

wds.worldbank.org/external/default/WDSContentServer/WDS P/IB/2004/07/26/000160016 20040726122452/Rendered/IND EX/E9680vol08.txt. Accessed on 22nd October 2014. 
[21] URT - United Republic of Tanzania, Ministry of Agriculture and Food-Security (2003). River basin management and smallholder irrigation improvement project (RBMSIIP): Small holder irrigation improvement component: Mangalali irrigation scheme, environmental audit, Draft Report E968, Volume 3. Environmental resources consultancy, consulting environmental conservation. Natural resources management and capacity building. http://wwwwds.worldbank.org/servlet/WDSContentServer/WDSP/IB/200 4/07/26/000160016_20040726121017/Rendered/INDEX/E96 80vol03.txt Accessed on 22nd October 2014.

[22] URT - United Republic of Tanzania, (2006). Water resources assistance strategy: Improving water security for sustaining livelihoods and growth, Water and Urban Unit 1, Africa Region, Report No 35327, The World Bank.

[23] Matsché, N and Kreuzinger, N (2001). Manual on chemical water analysis for the IPGL course / Water chemistry, Institute for Water Quality and Waste Management, Department for Chemistry and Microbiology, Vienna University of Technology, Austria.

[24] Greenberg, A.E., Connors, J.J. and Jenkins, D., Eds (2005).
Standard methods for the examination of water and wastewaters, 20th Edition, American Public Health Association(APHA), American Water Works Association (AWWA) and Water Pollution Control Federation (APCF).

[25] Weiner E (2008). Applications of environmental aquatic chemistry: A Practical Guide, 2nd Edition, CRC Press, Taylor \& Francis Group.

[26] Health Canada (2013). Guidelines for Canadian drinking water quality: Guideline technical document - Nitrate and Nitrite. Water and Air Quality Bureau, Healthy environments and consumer safety branch, Health Canada, Ottawa, Ontario. (Catalogue No H144-13/2-2013EPDF).

[27] WHO, (2011). Nitrate and nitrite in drinking-water: Background document for development of WHO Guidelines for Drinking-water Quality, Geneva.

[28] Tening, A. S., Chuyong GB., Asongwe G. A.,Beatrice Ambo Fonge B. A., Lifongo, L. L., and Tandia B. K., (2013). Nitrate and ammonium levels of some water bodies and their interaction with some selected properties of soils in Douala metropolis, Cameroon, African Journal of Environmental Science and Technology, Volume 7 Number 7, pp. 648-656. 